\title{
Writing Between Stillness and Movement: Script-Bearing Artefacts in Courtly German Literature
}

\section{Literary Contexts}

In the German-speaking medieval world, narrated inscriptions and extraordinary forms of writing occur with noticeable frequency in secular narrative poetry. During the High Middle Ages, this vernacular art of storytelling stretches across a network of well-established and well-connected aristocratic courts. Most of the Middle High German poetic texts were translated, re-told, written, copied, and performed in these contexts. Courtly literature flourished from the late twelfth century onwards before losing ground during the fifteenth and sixteenth centuries. Interestingly, the invention of movable type in the middle of the fifteenth century became a barrier courtly literature rarely passed. Courtly texts that were still deemed important after 1450 continued to be copied by hand, revealing their antiquity via their material presentation. Later, during the seventeenth and eighteenth century, these manuscripts were largely (though not completely) forgotten. It is to the credit of Romanticism and early "Germanic Studies" (Germanistik) that the narrative culture from the twelfth to the fourteenth century was finally transposed into print culture and popularised again.

Courtly literature's appearance and long-lasting success was mainly due to far-reaching social and political transformations in the High Middle Ages. These transformations led to the growing interest of (presumably) scarcely educated noblemen and noblewomen in various forms of writing that facilitated administration and governance. This interest likely led, in turn, to the increasing importance of script and writing within the story-worlds themselves. Consequently, narrated inscriptions and extraordinary forms of writing offer us a chance to think about the role, the scope, and the limitations of this once innovative and influential technique called writing. To put it plainly: when courtly literature deals with extraordinary forms of writing, it also deals with a comparatively novel and fascinating phenomenon-a phenomenon whose potentials and boundaries were not yet clear.

Admittedly, there is another reason why, for the German nobility, the advent of courtly literature was of tremendous importance. Courtly literature allowed German nobles to participate in a kind of self-fashioning through textual culture; it helped

This publication originated in the Collaborative Research Centre 933 "Material Text Cultures. Materiality and Presence of Writing in Non-Typographic Societies" (subproject C05 "Inscriptionality. Reflections of Material Text Culture in the Literature of the 12th to 17th Centuries"). The CRC 933 is funded by the German Research Foundation (DFG).

๑ Open Access. (c) 2019 Laura Velte and Michael R. Ott, published by De Gruyter. (c) BY-NC-ND This work is licensed under the Creative Commons Attribution-NonCommercial-NoDerivatives 4.0 License. 
shape a shared code of conduct, and it ultimately enabled the German nobility to strengthen its position vis a vis the Church. For many centuries, the Church had not only administered Christian knowledge and faith but also jealously guarded classical secular knowledge by firmly controlling the written discourse network. In the course of the twelfth century, however, the Church lost its educational monopoly. Numerous dukes and princes now began to support the arts and sciences at their local courts, in competition with the imperial court, the only secular body traditionally responsible for the promotion of (Latin-based) education. In these new courtly contexts the development of chancelleries encouraged new forms of administration with a consequent increase in Latin writing. This enabled princes and dukes to emerge as patrons for art and vernacular literature by using the potential of textual production to put relevant narratives down in writing. In doing so, these princes and dukes managed to gradually establish a distinct culture that was vernacular, courtly and, in many ways, textual.

France was the main source for this courtly culture and initially its most important model. In fact, German epic poetry of the late twelfth and thirteenth centuries is largely based on three thematic cycles taken from contemporary French literature. These cycles focus on legendary historical periods: the Matter of Rome features tales from ancient epics, like the Trojan War, the life and deeds of Alexander and the wanderings of Aeneas. The Matter of France comprises the legends of Charlemagne and Roland, for example; and the Matter of Britain focuses especially on legendary material associated with King Arthur and the Knights of the Round Table.

Due to this orientation towards France, many accounts of script in German literature have their origins in French and Occitan literary culture. This does not mean that German narratives merely copy their French sources. The "re-told" narratives-far from being translations in a contemporary sense-were adjusted to meet the expectations and knowledge of a particular audience. ${ }^{1}$ Well up to the fourteenth century, this audience generally was composed of mostly illiterate noble laymen and women at regional courts. Eventually, from the fourteenth century onwards, the cities (especially the imperial cities) became more and more important as places for the production, reception and transmission of texts and stories, which again changed the topics, forms and the dissemination of vernacular literature.

These changes significantly affected the interest in writing and manuscript culture and, in turn, the representation of writing in literary story-worlds. Prose romances (Prosaromane), for instance, provided a new form, which helped to gradually transform literary aesthetics and to establish new topics more relevant to the interests and concerns of townspeople. In these Prosaromane writing is often depicted as a rather ordinary act of communication and of managing everyday life. Romances in prose became more and more common during the fifteenth century and flourished during the following century. Finally, in the seventeenth century, the new and fashionable genre

1 Influential for the German discussion on translation and retelling has been Worstbrock 1999. 
of pastoral poetry featured numerous inscriptions on trees and wood, a material that was, as the corresponding article in this volume explains, hardly used for writing in medieval times. Established in the twelfth century, the German tradition of narrated inscriptions and extraordinary forms of writing came to an end almost five hundred years later.

\section{Narrated Inscriptions}

Our discussion of narrated inscriptions as extraordinary forms of writing will focus on courtly literature and consequently on the period from the twelfth to fifteenth centuries. We will not cover all genres, however, because not all genres engage significantly with script-bearing artefacts. Lyric poetry, for instance, seldom contains discussions or descriptions of writing. This might be due to lyric poetry's profound connection to live performance and orality. One important and illuminating exception which proves the rule, a love-song by Heinrich von Morungen, will be our first example. Heroic poetry (Heldenepik) is likewise primarily engaged with oral communication. Heroic poems like those featuring Theoderic the Great (Dietrichepik) and even the rather courtly Nibelungenlied demonstrate a rather conspicuous disregard for script and writing, preferring messengers to letters and oaths to charters. As interesting as this may be, we will omit heroic poetry and instead cover narrative texts, especially romances and various shorter narratives. The longer narratives include Arthurian romances like Hartmann von Aue's Erec, adaptations of French Chansons de Geste like the accounts of Roland and William of Gellone, and Gottfried von Straßburg's version of Tristan and Iseult. While some of the script-bearing artefacts in these texts are mentioned only in passing, others, like the grail in Wolfram von Eschenbach's Parzival, play a major role and reveal what is at stake with writing beyond pen and parchment.

A considerable number of inscriptions in courtly literature are fanciful and highly symbolic. They can be very long, extremely valuable, elaborately manufactured, or even magical. Although narrative worlds contain many different things (including the fantastical or magical), there is, as a matter of principle, no need to explain where these artefacts came from or how they were produced. Rather, German medieval narrations instead show a profound interest in detailed descriptions of the things themselves. Narrators do not just guide their recipients through the story, but invite them to look closely at the prepared artefacts of the imaginary world. Ekphrasis-or descriptio, as this rhetorical technique was called in the Middle Ages-is adapted from ancient epic. It reserves a space inside the narrative to reflect on materiality, focussing not on production but on the extremely artful nature and texture of artefacts. ${ }^{2}$

2 See Wandhoff 2003. Wandhoff's book is the most important recent contribution to ekphrasis in German. 
Inscribed tombs especially invite an ekphrastic focus that highlights not so much the engraved texts, which tend to be short and formulaic, but brings out the ornamental shape and extraordinary material of the artefact. ${ }^{3}$ Such elaborately worked inscriptions engage the senses of sight and touch first before inviting the onlooker to process them cognitively, through reading and interpretation.

Our interest in narrated inscriptions in German courtly literature has some scholarly predecessors, as this volume's introduction has pointed out, but our comprehensive approach does not. Previous studies mostly tried to register and arrange collected text passages and to compare the findings to real inscriptions. We will instead consider script-bearing artefacts as an independent phenomenon not necessarily linked to real artefacts. Moreover, we propose to treat narrated inscriptions as starting points for readings of the particular text and as clues to medieval engagements with script and writing. ${ }^{4}$ In choosing our examples we rely on the CRC database and the collection it provides. We have already (as of October 2018) catalogued 95 relevant German works up to the year 1500. And from these 95 works we collected 195 relevant passages, some of which include several script-bearing artefacts. The database entry on Wolfram von Eschenbach's romance Parzival, for example, lists an astonishingly high number of 11 text passages featuring inscribed objects, although the number of artefacts is in fact less because some artefacts are mentioned repeatedly. ${ }^{5}$ In contrast, Wolfram's epic poem Willehalm offers only three passages. The first one simply refers to an epitaph found in Parzival; the second one mentions a cross attached to a garment that resembles the Greek letter tau. The third and most interesting one refers to name tags that identify dead heathen kings and attributes the practice of material writing to cultural "others". This difference in the treatment of inscriptions in works by the same author highlights the significance of generic distinctions, demonstrating that epic poetry and similar texts only sporadically include script-bearing artefacts.

Objects of the literary worlds appear primarily as "artefacts". This is to say that things like clothes, brooches, weapons and tombs are manufactured and shaped by human or divine artistry. We can distinguish between materials used for writing and materials serving as a ground and surface for writing. Materials mentioned in German medieval literature often reflect a courtly desire for representative artwork employing precious materials such as gold, various metals, diamonds, textiles and glass, and natural materials such as stone and wood. Narrations of script-bearing artefacts, however, do not always provide information about their specific materials or about the specific script they bear, or about the writing technique. Even so, our database indicates that text-bearing artefacts in medieval German literature most often consist of metal (43 instances), textile (37), stone (27), gems (10) and wood (5). The most

3 Wandhoff 2003, 13-26.

4 For a more detailed discussion of our method see Lieb 2015.

5 Michael R. Ott's article on weapons provides a short summary of inscriptions in Parzival. 
common writing materials applied to a surface are gold (34 instances) and gems (7). As both materials are very precious, they bind the concept of writing to aristocratic opulence. Epitaphs are mostly said to be ergraben, a term commonly used in Middle High German to indicate carving, engraving, and chiselling. Writings on textiles are sometimes described as woven. In many other cases, however, the texts do not elaborate on writing techniques.

Our examples are organised according to two important and closely connected criteria: location and movement. We will discuss "locostatic" artefacts first to show how these artefacts create relationships to the past and to earlier texts (part 3). We then deal with tents as a rather special case, in that they create third spaces, spaces closely connected to (courtly) love (part 4). Finally, we will discuss "locomobile" artefacts (part 5). These artefacts mediate and bridge a distance-between lovers, for example, or between separated family members. In short: We speak about media relating to the past (locostatic), media relating to space (tents) and media relating to people (locomobile). A concluding section (part 6) enlists some recent scholarship by the CRC subproject $\mathrm{C} 05$ and reflects on its relationship to previous German collections of narrated inscriptions.

\section{Locostatic Artefacts}

"Has anyone seen the lady", the speaker in one of Heinrich von Morungen's poems wonders, "the lady we may usually observe while she is standing at the window?" (Sach ieman die vrouwen, / die man mac schouwen / in dem venster stân?, 129,14) ${ }^{6}$ It is she, the speaker claims, who once took away his sorrow with her resplendence, shining like the sun on a bright early morning. Now that she is gone, the speaker asks his audience for help, searching for someone who still has his wits about him. He should seek her, go to her, beg her to come back to console the speaker before he dies because "pleasure and pain", he says, will soon take him to his grave. ${ }^{7}$ The speaker asks for a last favour:

\footnotetext{
6 Morungen probably imitated the technique of epigrammatic (or, more specifically, epitaphic) writing used already in ancient literature and especially by roman love elegists (see Ramsby 2007; Keith 2011). Particularly Ovid's Heroides contain a great number of epitaphic minded passages (2.147f.; 7.195f.; 14.129f.; 15.183f.).

7 Ist aber ieman hinne, / der sîne sinne / her behalten habe? / der gê nach der schônen, / diu mit ir krônen / gie von hinnen abe; / Daz si mir ze trôste kome, / ê daz ich verscheide. / diu liebe und diu leide / diu wellen mich beide / vürdern hin ze grabe $(129,25)$. Unless an English translation is given with the text edition in the bibliography, the translations are ours.
} 
Wan sol schrîben kleine

reht ûf dem steine,

der mîn grap bevât,

wie liep sî mir waere

und ich ir unmaere;

swer danne über mich gât,

Daz der lese dise nôt

und ir gewinne künde,

der vil grôzen sünde,

die sî an ir vründe

her begangen hât.

$(129,36)$.
Someone shall write, with small letters,

right onto the stone,

which will cover my grave;

shall write how much I loved her

and that she despised me.

Whoever will walk above me

shall read this misery

and find out about

the great sin

she hitherto has committed against him

who loved her.

This poem, probably written in the late twelfth or early thirteenth century, leads right into the textual world of courtly culture. It deals with an elaborate configuration of heterosocial relations, constructing an arrangement of men, women and desire commonly referred to as Minne ("courtly love"). But this poem also gives us a glimpse of the relevance, capacities, and facets of inscriptions in medieval German literature. The poem's imagined epitaph consists of certain materials and possesses a certain physical concreteness. It occupies a place and it creates a topological space. It evokes sundry practices and, of course, transmits a message. The criteria elaborated in the introduction to this volume (materials and materiality, topology and mobility, practices) invite a more detailed analysis of Heinrich von Morungen's poem.

The tomb consists of stone, a durable material, not easy to inscribe, but suitable for long-lasting readability and for sustained remembrance. Usually, writing on stone establishes a much more intense relationship between the text and its material than writing on a wax tablet or parchment. That is why lithic artefacts already make a statement by themselves. ${ }^{8}$ Though we do not know much about the exact spatial position of the speaker's tombstone, it obviously is positioned on the ground. We should bear in mind that this was quite common in the late antique world and in the European Middle Ages. ${ }^{9}$ But this very tombstone and its epitaph nevertheless create a specific space for movement and for communication between the dead and the living. To establish this space, the speaker needs someone to write the epitaph, someone who organises the remembrance according to the speaker's will.

But how are we supposed to imagine the material and spatial arrangement of this imagined inscription? Since it is possible to walk over the stone and the written words, the tombstone lies underfoot, maybe in a cemetery or in the floor of a church. The poem does not give much detail about the surroundings, either because this information is not important or because the recipients were supposed to have possible surroundings in mind. Interestingly, though, the speaker demands that the letters be

8 For a comprehensive view of stone see Cohen 2015.

9 Lieb/Wagner 2017, 24. 
small. Conceivably, the inscription would not be readable by someone standing above the grave. To read the words, one may have to bow or even kneel and, in doing so, come closer to the dead. The inscription on the tombstone "is designed to affect bodies, to influence their movements and to incite them to read, to speak for the dead lover who had never been able to express his affection while alive" $\cdot{ }^{10}$ Finally, the epitaph not only tells its reader about the relationship between the speaker and the lady but informs the lady of her blameworthiness. Far from a neutral message, the words have an addressee, they are chosen with the intention to affect somebody.

It would be tempting and certainly interesting to compare this poem and its imagined epitaph to other poems dealing with script-bearing artefacts. Unfortunately, Heinrich von Morungen's poem seems to present the only transmitted example of a narrated inscription in Middle High German love lyrics. ${ }^{11}$ This may be due to a characteristic feature of medieval German love poetry: its orality. As the German term Minnesang with its emphasis on singing readily suggests, the "love songs" were meant to be staged in front of a courtly audience, performed by experienced entertainers who put themselves in the position of the lover. As Morungen's poem illustrates, Minnesang itself often talks about its own nature as oral communication. In Morungen's poem the speaker addresses the audience directly, referring to the present moment-the "here and now"-in asking for help to connect with his lady. Minnesang's emphasis on orality often displaces any concern with writing. If we want to search for narrated inscriptions in medieval German literature we have to turn our attention away from lyric poems and towards epic poetry.

Tombstones are locostatic artefacts, closely related to their devised place and not easily moved. The largest group of locostatic artefacts (about 30 references in our database) is mainly composed of gravestones and sarcophagi. The comparatively high number of results in this category may reflect the important role played by sepulchral writing in the Middle Ages in general. ${ }^{12}$ Apart from religious and clerical contexts (church, cloister, and scriptorium especially), epitaphs probably formed the most frequent and ubiquitous form of writing that was visible to everyone. Because they emerge with the deaths of those they commemorate, epitaphs paradoxically stand for both presence and absence. When death forces beings into representation, their tombs become complex signs that condense and solidify biography, but also address those left behind, linking past to present life. ${ }^{13}$

10 Lieb/Wagner 2017, 24.

11 There are, though, three narrated inscriptions in poems by Hugo von Montfort. But he writes his poems around the year 1400 (about two hundred years later than Heinrich von Morungen). And his poems cannot be compared well with classical Minnesang (see Hugo von Montfort 2005, poems No 4 and 28). Christine Neufeld's article on architecture in this volume provides some details on inscriptions in Hugo von Montfort's work.

12 See especially the fundamental study of Petrucci 1998.

13 See Laura Velte's article about tombs and epitaphs in this volume. 
A romance about Alexander the Great by Lambrecht the Priest provides one of the earliest narrated epitaphs. The artefact here operates as a carrier and transmitter of a distant historical past. In the middle of the twelfth century, when this romance was written, such a connection to the past was of the utmost importance. Authority relied on tradition and tradition required a connection to relevant people and occasions of the past. This lies at the heart of the notion of translatio imperii. Accounts of Alexander the Great participate in and illustrate this idea of a "migration of authority”. When Alexander's men in Lambrecht's romance, like archaeologists, excavate a vitreous sarcophagus, they unearth an even more distant past as well. Through the sarcophagus's green translucent glass they can identify a corpse and an inscription revealing the name of the dead man: "His name was Evilmerodach. He had been the king of Babylon” (Er hîz Evilmerodach, / der kuninc in Babilonia was, 3114f./3566f.).

While the Alexanderroman offers the earliest, Wolfram von Eschenbach's Parzival features the most flamboyant epitaph in the German corpus. Probably written during the first two decades of the thirteenth century, Wolfram's text retells and thereby refashions Chrétien de Troyes's Perceval, making it suitable for his courtly German audience. Yet, the first part of Wolfram's romance does not appear in Chrétien's Perceval and was most likely invented and added by Wolfram himself. This first part recounts the life and death of Parzival's father, Gahmuret. He is an outstanding knight, impulsive, restlessly peripatetic, and to some extent untameable. Gahmuret marries Herzeloyde, Parzival's mother-to-be, only to leave to fight for a Muslim king (the Baruch) and die in combat far away from home. When, shortly before Parzival is born, Gahmuret's squire delivers the news of Gahmuret's death to his wife he recounts the circumstances of the death, and describes the hero's exceptional tomb, and the epitaph engraved in Gahmuret's helmet, called “adamant”: ${ }^{14}$

In sînen helm, den adamas, / ein epitafum ergraben was, / versigelt ûfz kriuze obeme grabe. / sus sagent die buochstabe. / "durch disen helm ein tjost sluoc / den werden der ellen truoc. / Gahmuret was er genant, / gewaldec künec übr driu lant. / ieglîchez im der krône jach: / dâ giengen rîche fürsten nâch. / er was von Anschouwe erborn, / und hât vor Baldac verlorn / den lîp durch den bâruc. / sîn prîs gap sô hôhen ruc, / niemen reichet an sîn zil, / swâ man noch ritter prüeven wil. / er ist von muoter ungeborn, / zuo dem sîn ellen habe gesworn: / ich mein der schildes ambet hât. / helfe und manlîchen rât / gap er mit stæte'n friunden sîn: / er leit durch wîp vil schärpfen pîn. / er truoc den touf und kristen ê: / sîn tôt tet Sarrazînen wê / sunder liegen, daz ist wâr. / sîner zît versunnenlîchiu jâr / sîn ellen sô nâch prîse warp, / mit ritterlîchem prîse er starp. / er hete der valscheit an gesigt. / nu wünscht im heiles, der hie ligt.” / diz was alsô der knappe jach. (107,29-108,29)

Upon his helmet, the adamant, an epitaph was engraved, sealed upon the cross, above the grave. The letters read thus: "Through this helmet a joust slew this noble man, bearer of valour. Gahmuret he was named, mighty king over three lands, each of which acknowledged his crown. Powerful princes walked in his train. He was born of Anjou, and before Baldac he lost his life,

14 For more recent thoughts on Gahmuret's grave see Lembke 2017. 
in the Baruch's cause. His fame shot so high that no-one can match its mark, no matter where knights are tried today. That man is unborn of mother to whom his valour swore surrender-I mean those who have the shield's office. Help and manly counsel he gave with constancy to his friends. For women's sake he suffered most sharp pangs. He bore baptism and Christian faith. His death grieved Saracens-that is no lie, but the truth. All the reasoning years of his times, his valour so strove for fame that it was with knightly fame that he died. He had won the victory over falsity. Now wish salvation to him who lies here.” This was what the squire averred.

So what are we to make of this excessively detailed inscription on an extraordinary artefact? First of all, the inscription is written on a helmet that is fixed on top of a cross erected at the head of Gahmuret's grave, "mirroring the position of the inscription affixed to the cross of the dying Christ", one of the most famous and most commonly known inscriptions of the Christian Middle Ages (cf. John 19:19-20). ${ }^{15}$ Second it is questionable that Gahmuret's helmet would have offered enough space for such a long inscription, featuring such a detailed narrative. At second glance, however, it remains unclear if the squire is really, as he states, quoting the inscription ("The letters read thus"). The crucial passage, unsettling the audience's trust in verbal citation, starts with the qualification, "I mean". This interjection interrupts the announced quotation with an explanation, suddenly mingling literacy and orality. In this case, as on many other occasions, narrated inscriptions are not a word-for-word rendering but a narrative device, connecting materiality, writing, reading, and, in case of epitaphs, remembrance and mourning.

To medieval recipients, the presentation of Gahmuret's tomb must have been remarkable and exemplary. Wolfram even mentions this tomb in his Willehalm, creating an explicit intertextual connection. And the fame of the tomb is also illustrated by further references to Wolfram's text, for example, in Wirnt von Grafenberg's Arthurian romance Wigalois (early thirteenth century). Obviously, narrated epitaphs not only provided connections to distant pasts but also generated intertextual connections between literary texts.

In Wigalois, written presumably shortly after Parzival, we come across another funeral arrangement, once again embedded in an environment of paganism: after a furious battle, the outstanding knight Wigalois, having been assigned the task of reconquering the kingdom of Kornint, kills the heathen usurper Roaz of Glois, who is said to have made a pact with the devil. Devastated by his demise, Roaz's virtuous wife Japhite immediately follows him into death. Shortly thereafter she is buried in a coffin of red hyacinth filled with burnt balsam and put on two columns of ore. The sepulchral monument is said to be a work commissioned by her husband while he was still alive; but apparently the epitaph must have been created afterwards. Made of golden letters moulded directly onto the precious stone, the writing reports Japhite's

15 Lieb/Wagner 2017, 21. Ricarda Wagner's article on tablets in this volume elaborates on the INRI inscriptions as a premodern post-it. 
whole biography in 29 verses and asks its readers to pray for her intercession. The inscription is just as detailed as Gahmuret's epitaph. In fact, the narrator explicitly refers to his literary model:

\author{
wart Gahmuret ze Baldac \\ von dem bâruc bestatet baz, \\ deiswâr, daz lâze ich âne haz, \\ wand er hêt grôze rîcheit. \\ (8244-8247)
}

\author{
Had Gahmuret at Baldac \\ been entombed better by the Baruc? \\ Truly, I'll leave it at that without hatred, \\ because he enjoyed vast riches.
}

With this brief intertextual reference to the tremendous wealth of the Baruch, the narrator ironically excuses the less opulent monument in his own narrative. However, quoted directly by the authorial narrator, and not transmitted by one of his characters as in Parzival, the inscription in Wigalois gains a more reliable and factual quality.

Both examples vary in the way they symbolically exhibit the conflict between Christianity and paganism. Gahmuret, a Christian warrior in the service of a Muslim ruler, is buried far away from his own kingdom, but still in a tomb that features Christian symbols and with an inscription in the language of his compatriots. By contrast, Japhite, the pagan queen, is buried in her own kingdom, but in a tomb marked by Christian beliefs, requesting that visitors or travellers pray for the spiritual salvation of the unbaptised queen. That is why the epitaph is issued bilingually, in French (franzois) and a pagan language (heidenisch). It is not evident, however, who the author behind the inscription actually is. A converted heathen named Earl Adan is reported to have knowledge of both languages, yet it seems rather unlikely that a passing heathen would intercede with the Christian God for the lady's salvation.

Since gravestones do not necessarily reveal their authors but nevertheless have a certain authority once they are erected, they can function as important signifiers of power. They address those left behind and shape their memory about past events and political order. In this sense, Japhite's bilingual epitaph indicates a significant transformation of the cultural landscape of Kornint. Not only has the era of pagan domination ended, but even remnants of that era have fallen under the control and ideology of the new Christian sovereigns.

Epitaphic writing as a strategy of cross-referencing can also be observed elsewhere in medieval literature, although it might aim at different effects. As the example of Wirnt von Grafenberg demonstrates, epitaphs can refer to epitaphs in other narratives and highlight the intended appropriation of the art of storytelling by one poet from another. But epitaphs can also function as cross-references within the same narrative and develop a metapoetic function, as in the vast and entangled network of romances about Lancelot. ${ }^{16}$ Inscriptions in these narratives commonly serve the purpose of

16 See Colliot 1973; Maddox 2000; and with special regard to the German version see Witthöft 2013. 
authentication: they are considered reliable traces that confirm the historical truthfulness of antique mythological events. Laura Velte's chapter on tombs in this volume will elaborate this discussion.

Another example of such cross-references occurs in relation to one of the few inscriptions on trees in medieval German literature. In Konrad von Würzburg's Trojanerkrieg (c.1280) Paris is said to have carved an inscription into the bark of a tree in order to comfort his beloved Oenone and allay her concerns about his faithfulness. But, ironically, the durability of the tree inscription ultimately becomes a testimony of his infidelity. Paris's beautifully carved lines will become a symbol of a significant historical turning point. Not only will he change his own mind by falling in love with Helena, but he will seal the fate of the whole Trojan nation. ${ }^{17}$ While the chapter on wood inscriptions explores this particular inscription in more depth, we want to draw attention here to the role Paris's hand-carved inscription plays in the vast narrative tradition based on the life and the great campaigns of the heroic commander Alexander the Great. The version of the popular Alexander romance by Ulrich von Etzenbach (written in the second half of the thirteenth century) comprises around 30.000 verses and, unlike earlier versions, contains various narrated inscriptions. They emerge particularly at the point when Alexander in the course of his conquests reaches the territory of Ancient Troy. Before he enters the battleground covered with epitaphs commemorating the deeds of the ancient heroes Alexander passes the forest of Ida and discovers an old inscription that Paris had carved into a poplar tree:

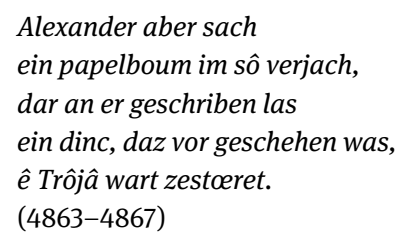

And now Alexander saw a poplar, revealing itself, and he read what was written on it, about an affair that had happened before, before Troy was destroyed.

Mentioning the Trojan War here serves as a literary backdrop for Alexander's own aspirations to power. Within this context, Paris's spontaneously carved inscription features as a topological landmark indicating Alexander's entry into a legendary realm: reading the inscription reveals a historical event that has unfolded during a time the Macedonian would recognise as the ancient past. As a quite durable artefact the tree inscription can be found, looked at and interpreted as a relic of a distant past. For the medieval audience Alexander's walk through Troy becomes a "recursive panorama" of antiquity, interlacing two important narratives from the same thematic cycle (the Matter of Rome) and thereby revealing different phases of the historical past. ${ }^{18}$ In this panorama inscriptions on wood and stone act as reminders and witnesses of a process of historicisation.

17 The episode is probably based on Oenone's letter to Paris in Ovid's Heroides (5.21-32).

18 For a detailed discussion of these aspects see Laura Velte's forthcoming PhD thesis. 


\section{Pitching Tents}

In addition to epitaphs, other kinds of locostatic inscriptions can be found on columns or statues as well, either inside or outside of buildings, and sometimes on architectural structures marking transitions and passages, like archways for example. Our database contains 33 inscriptions connected to buildings. This includes six cases of inscriptions on tents, an artefact that complicates Ehlich's distinctions between the locostatic and the locomobile. ${ }^{19}$ Tents are mobile but provide a fixed residence for a certain amount of time. They often underline claims to power when erected outside of someone else's domain..$^{20}$ But tents can also be introduced in order to create distinguished spaces, such as a "love-tent” (Minnezelt), which is usually embedded in a paradisiacal landscape that constitutes an entire realm of love. The only extraordinary form of writing in Hartmann von Aue's influential Erec (c. 1180), for example, consists of a conspicuously inconspicuous inscription on such a love-tent (8901-8957).

The tent appears at the beginning of Erec's very last adventure (known as the episode of Joie de la court). The hero encounters Mabonagrin, who lives in an isolated community with his beloved. Everyone who enters his garden is considered an intruder and is at risk of being killed immediately. When Erec reaches the location, a magnificent velvet tent catches his eye, featuring an almost cinematographic scene: the fabric depicts women and men, as well as birds that seem to be moving as if they were real; tamed and wild animals complete the picture, all of them portrayed with superscriptions revealing their names. Inside, Erec sees a beautiful lady with a precious dress, sitting on a bed made of silver. The extensive description of the tent makes it a symbol representing the otherness of Mabonagrin's realm: this tent serves as a place of harmony between men and women and as a place where nature and culture are reconciled. The inscriptions above the icons indicate a systemic order maintained in this territory. However, this order is written on a tent, revealing its temporary nature. And although the tent may separate a private inside from a public outside, the embroidery allows a glimpse into the lady's bedchamber, dissolving the boundaries between public and private.

The tent as a place of distinction appears in many more romances. Another one appears right in the middle of Lanzelet by Ulrich von Zatzikhoven (written after 1194). This tent is given to the hero after a series of adventures when he finally defeats his opponent, the knight Iweret, and marries his daughter Iblis. In this specific moment a messenger from his foster mother appears informing Lanzelet about his name and his origins. The tent is offered not only as a nuptial gift, but as proof of the messenger's truthfulness. Resembling the tent in Hartmann's Erec, it is likewise made of precious materials and adorned with pictures of birds that seem to be moving, and features a

19 Ehlich 1994.

20 See Stock 2005; Klingner 2013. 
golden gate with inscriptions. Although the narrator claims he is too far away to see properly, he presents the exact wording of the inscriptions:

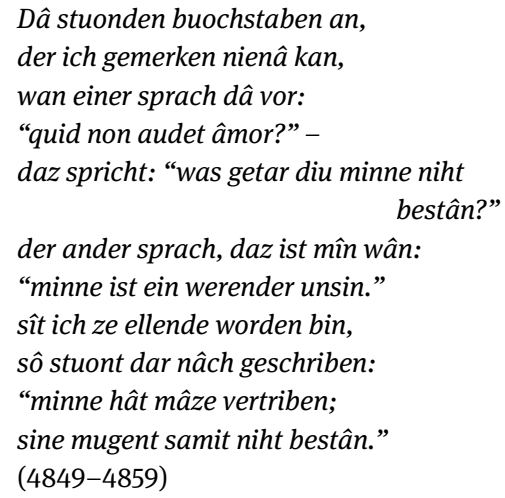

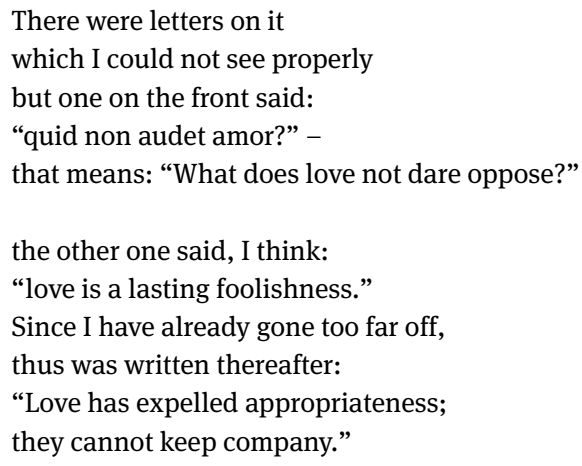

While in Erec the letters caption the animal pictures, the inscriptions in Lanzelet form short, aphoristic phrases that proclaim how travesty (unsin) and excessiveness prevail in the realm of love. The combination of Latin and vernacular adds up to a universal knowledge that the narrator, quoting what he cannot actually read, also possesses. Although in both examples love is characterised as an emotional state that is subject to distinctive rules, in Erec the love between Mabonagrin and his wife is presented as a rather artificial and vulnerable harmony; whereas in Lanzelet it becomes something desirable (literally a gift) that can be obtained by marriage, emblematically represented by the golden gate.

Script-bearing tents appear also in the rather allegorical worlds of so-called Minnereden ("speeches of love"), a genre obsessed with love and the social conventions surrounding it. Minnereden are defined as stand-alone texts in rhymed couplets circulating during the fourteenth and fifteenth centuries, mostly told by a first-person narrator. ${ }^{21}$ About 500 texts ranging from 10 to 6,000 verses are known. Although these texts have not received much attention in literary scholarship, they constitute the most extensive genre of German secular poetry in the late Middle Ages. ${ }^{22}$ Many Minnereden include personified vices and virtues and allegorical scenes, in which script-bearing artefacts-and inscriptions in particular-appear most frequently.

In Peter Suchenwirts Di schoen Abentewr (c. 1400) the speaker is walking through a beautiful spring landscape when he discovers a group of tents. One of them clearly stands out for its splendour. It consists of ivory poles, green and golden silk and a skylike ceiling of velvet that becomes darker towards the Occident and lighter towards the Orient. Pearls are embedded into the fabric creating a visible lettering, said to be

21 For a comprehensive overview see Klingner/Lieb 2013.

22 See Lieb 2008, 193. 
getzedlet-a rather rare German verb that can refer to a written note as well as to woven textiles:

Dar auf lag vil getzedlet

Der brief von perlein derhaben, Mit gold erlucht die buochstaben,

Die spruech von der mine

Aus maisterleichem sinne,

Der ich ain tail zu deutsche laz,

Auch maniger mir unchundig waz

Von vrantzois, von lateine.

(58-65)

\author{
There lay upon it, textiled, \\ the letter of sublime pearls. \\ Gold illuminated the characters, \\ the aphorisms about love \\ with masterly wisdom. \\ I read some of them in German. \\ But others were unintelligible to me, \\ in French, and in Latin.
}

As in Lanzelet, this tent is covered with sayings about love (spruech von der mine) in different languages. But unlike the omniscient narrator in Lanzelet, the speaker here admits that he cannot read what is written in French and Latin. Neither does he recognise the symbolic value of the tent right away: he expects it to be the property of a commander, but is corrected by a squire, who suddenly comes along and informs him about his mistresses, the personified virtues, Love and Honour. Subsequently, the speaker himself becomes part of the allegorical event. He meets the ladies of the house and witnesses a discussion between Love, Honour and Adventure on the moral decline at court. In contrast to what has been discussed earlier, the tent in Di schoen Abentewr not only offers a contextual explication of the nature of love, but marks the entry into an entire allegorical narrative world in which the script-bearing tent and the knowledge it conveys have become a distinctive literary topos. The moment of entering and leaving this world is constitutive for the whole genre of Minnerede and marked here (and elsewhere) by the speaker's lack of knowledge.

\section{Locomobile Artefacts}

Just like tents, locomobile artefacts are related to space but in a distinctly different manner. While tents provide a temporary room, locomobile artefacts can traverse space and change location. According to Konrad Ehlich, they may generally be less durable than locostatic artefacts; but that is precisely why they can overcome the barriers of space and why they can generate multiple situations of reception and communication. These mobile artefacts mediate and convey, as our examples will show, between separated individuals or places, between lovers, for instance, and between separated family members.

Unlike immobile artefacts, locomobile artefacts generally do not function as carriers for collective commemoration, but rather preserve a personal memory. They often combine physically with persons-as weapons, which become "prostheses" of the 
human body, or as clothing, which can form "a second skin". That is why transportable and inscribed artefacts often provide information about a specific person, such as a name or a moral virtue. Moreover, locomobile artefacts tend to be involved in rather private situations. In Tristan by Gottfried von Straßburg (c. 1200) a thin piece of wood with the initials of Tristan and Isolde becomes the agent of a secret communication between the king's nephew and the queen. Floating on the river the message surmounts the social and spatial barriers between the two lovers and reaches its exclusively intended addressee (14421-14444).

Locomobile artefacts, then, are often personal artefacts. The Song of Roland, retold in German by Konrad the Priest at around 1170, provides a vivid example. As a hero, Roland is uniquely associated with material culture. Most famous are Roland's sword, called Durendart, and his horn, called Olifant. His elaborate and magnificent armour complements these two artefacts. Before the crucial battle of Ronceval, the narrator carefully describes how Roland puts on his armour: first donning a brightly glowing tunic, then his helmet, sword, and trousers, and finally, before climbing on his horse, grabbing a spear. While the horn's sole purpose is communication, Roland's helmet is the thing that speaks:

\author{
der helm hiez Venerant, \\ den der helt ûf bant, \\ mit golde beworchten, \\ den die haiden harte vorchten. \\ mit guldînen buochstaben \\ was an der lîsten ergraben: \\ "elliu werlt wâfen, \\ die müezen mich maget lâzen. \\ wilt du mich gewinnen, \\ du füerest scaden hinnen." \\ (3291-3300)
}

\author{
The helmet the hero put on \\ was called "Venerant", \\ embraced with gold- \\ the heathens feared it. \\ Golden letters \\ were inscribed on the metal stripe: \\ "All the weapons of the world \\ have to leave me a maid. \\ If you try to capture me, \\ you'll carry damage away with you.”
}

Roland's helmet interestingly and exceptionally claims to constitute a body of its own, referring to its own maidenhood, incarnating and gendering itself. Consequently, we may assume two bodies that coexist: the body of Roland and the body of the helmet. The helmet's body is clearly marked as a virginal female body, imposed on a man to protect him. Not only does this assemblage create a bi-gendered warrior, it also links the fighting to sexual intercourse, even to notions of rape. And yet the virginal helmet presents herself as strong, well-equipped and able to defend herself, articulating a self-confident femininity.

A second crucial feature of Roland's helmet is its voice, whose prosopopoeia anthropomorphises the artefact even more strongly and endows it with agency. This is one of the rare cases in German literature when an artefact "speaks" in the first person via its inscription. Yet, the range of this voice remains unclear: to whom and how does the helmet speak? Does the helmet speak to the enemies, the so-called heathens? Can 
they read the text or have they read it before? And is it the inscription in particular that increases the fear of the pagans? Certainly, the helmet's inscription and voice participate in negotiations of power, codifying emotions and heroic superiority. And yet the inscription is actually inadequate, even wrong. Although Roland is the uncontested hero of Rolandslied, he will nevertheless die because he refuses to call for help. The inscription on his helmet articulates a heroic claim that marks the ambivalence of the hero.

Although Roland's helmet is exceptional, narrated inscriptions on weapons are not unusual. They express courtly literature's interest in knightly and martial culture. And they establish a triangular relationship between person, weapon and script. ${ }^{23}$ Inscriptions on weapons play an important role in our corpus of locomobile script-bearing artefacts. We have collected 47 inscriptions that belong to clothing and weapons. Twenty passages refer to weapons in particular. We found five inscriptions on helmets, six on shields, one on a lance, one on a lance's banner, one inscription on a sword's scabbard, and one on a sword's grip. This type of inscription seems to be less suitable for conveying a lot of information, but enhances the individuality of its carrier, especially by presenting his name. The inscription's role in "speaking” about a person or revealing his name means it frequently asserts or announces a person's status as a hero. The weapon can be so connected to its bearer as to actually become a part of him, an argument this volume's article on weapons will elaborate.

Roland's helmet is also a vivid example for the agency of material things. Artefacts may have a distinct capacity to act, to influence, and even to move. This anthropomorphic quality of things becomes all the more apparent when there is an exclusive connection between person and thing, such as clothes that lie on the body like a second skin or weapons that lengthen or enlarge human limbs. Often, the writing on these things only names or praises features that characterise the carrier and preclude possible expropriation or usage by someone else. Like gravestones, which contain the same basic information, locomobile artefacts work metonymically.

Locostatic artefacts (such as inscriptions on stone, wood, architecture etc.), in contrast, function as durable placeholders that provide insight into a narrated or legendary past. The narration of such script-bearing artefacts is therefore often selfreferential or, if the narrated past is part of another text, achieves an intertexual or metatextual dimension. Things that are neither clearly locostatic nor locomobile constitute a special case. In our examination, this was true of transitory tent rooms that reveal a homogeneous order inscribed in the walls that delineate the room. In such distinguished spaces, inscriptions work by depicting, exhibiting and affirming the spatial principles that apply as soon as the tent is entered.

In courtly communication, written artefacts have a special status: sometimes they remind and comment on (narrated) events, sometimes they indicate affiliations,

23 For more details and discussion see Ott 2015a. 
sometimes they constitute spatially limited orders of knowledge; but for their internal and external readers, they always bridge the manifold boundaries of space and time that are created by narratives. Especially courtly literature of the thirteenth century shows a great interest in the rich and multiform world of things; mediality must therefore always consider materiality.

Wolfram von Eschenbach's fragmentary Titurel (c. 1220), a kind of prequel to Parzival, proves this point. In Titurel a young couple unexpectedly encounters a hound with an exceptional leash. The hound, following the scent of its prey, had run away from its owner. The hound's leash is made of silk of four different colours, studded with rings and pearls that again frame four four-coloured leaves. Letters made of gemstones and fixed on the cord with golden nails appear underneath those leaves. Never, the narrator observes, has a hound ever been equipped with a better leash or a leash with a better hound (147,2-3). By equating the value of hound and leash, the narrator anticipates what follows: eager to learn the conclusion of the story told on the leash, Sigune unknots the leash from the tent pole. The hound runs away and leaves the maiden with a deep wound in her hand where the leash, abruptly yanked away, had cut into her flesh. In Titurel the material is simultaneously desirous and threatening. Closely linked with the hound, the artefact and the alphabetic characters have produced an uncontrolled agency. Artefact and writing are materially conceptualised in a way that undermines their expected usage. No longer do they fit specific human demands in the context of hunting. As an assemblage, hound and leash produce an extremely variable affordance enabling them to develop their own dynamics and to act unpredictably upon the human world.

Another important example of a thing's agency is the wax tablet in Hartmann von Aue's legendary tale Gregorius, written around the year 1200. Saints' legends include references to writing more often than courtly literature because such legends tend to be products of clerical literacy and closer to biblical-that is, written-tradition. Of course, the wax tablet itself is hardly an unusual artefact. Though seldom mentioned in courtly literature, wax tablets are a common and convenient artefact for writing in the Middle Ages. ${ }^{24}$ The malleability of wax meant that such tablets could be used for hasty notes or to compose a text that would be carefully written on parchment afterwards. What makes the tablet in Gregorius special is its significant role in the story, its "biography", and, in particular, its extraordinary usage.

At the beginning of the narrative, the wax tablet functions as a kind of identity document, or passport, as well as a set of instructions. Gregorius is the offspring of an incestuous relationship between noble siblings. To hide the sin, the child is put into a vessel and left on the sea. Into the vessel, his mother also places some splendid silken fabric, twenty marks of gold, and an ivory tablet, adorned with gems and inscribed by

24 Cf. Ricarda Wagner's chapter on tablets in this volume for more examples. 
her own hand (as the text emphasises). The text on the tablet explains that the child is of noble birth, and that his mother is his paternal aunt, and his father his mother's brother. Moreover, the text on the tablet explains that the child was left on the sea to hide the evil deed, but that the child should be baptised and brought up with the help of the gold. If its finder proves to be a Christian, he should increase the treasure and teach him to write so that he is able to read the tablet himself in order not to become presumptuous, and to make amends for his father and commemorate his mother.

For every step in Gregorius's life the wax tablet is decisive. His mother's inscription of her sin and her child's identity joins together the artefact and the child she sends out into the world. Later the vessel is rescued by fishermen and discovered afterwards by the local abbot during a stroll along the beach. Although the fishermen try to hide the child in order to keep the gold, the abbot hears the baby crying and takes the fishermen to task. While one of the fishermen is appointed to raise the child, the abbot, who names the child after himself, determines that Gregorius should become a monk in the local monastery. Because of the tablet, therefore, the child receives a favourable education. However, no matter how hard the local abbot tries, Gregorius would rather become a knight than a monk, especially after the abbot gives him the tablet proving his noble pedigree. As a young knight, adorned with the silk his mother gave him, he sails to his ancestral lands. There he rescues a damsel in distress, whom he marries, only to discover that she is in fact his mother. Interestingly, his mother recognises the silk he wears but discounts her own material evidence, choosing to disregard the idea that she could be encountering her own son. While the sartorial evidence is rejected, the textual evidence is unequivocal: The tablet finally reveals the truth, forcing them to confront their incestuous relationship, and driving Gregorius to perform extreme acts of penitence by becoming a recluse on a small island for seventeen years. ${ }^{25}$

The presence of the tablet highlights the protagonist's state of sin. Gregorius's time as a recluse is marked by the absence of the tablet-which he was forced to leave behind-allowing him to slowly cleanse his compromised spiritual condition. Gregorius's transition from recluse to religious leader reintroduces the tablet as a crucial part of his identity. When Gregorius is found by two Roman citizens commanded by God to appoint him as the new pope, Gregorius first of all searches for his tablet, which was buried by a burnt down stable. Although his companions assume it was destroyed, Gregorius finds his tablet, "as new as when he, who had made it, gave it away" (Gregorius, 3734f.). The tablet is now blank and, miraculously, it looks brandnew. The renewed and clean tablet shows that Gregorius's life of deprivation as a recluse has enabled him to reach a sin-free state. We may understand this as a divine

25 It is worth mentioning that the story and the script-bearing artefact show some similarity to Marie de France's lai Le Fresne which tells of the reunification of mother and daughter due to a script-bearing ring and a splendid brocade. 
miracle demonstrating that God has wiped away the sins of his designated pope. Its mission accomplished, the tablet is not mentioned again; and Gregorius can rise to the highest Christian office. The tablet “prescribes” in a very literal sense Gregorius's path of life and it is marked with traces of the absent mother who exerts influence via the artefact. As a historical sign it identifies but also marks him. And as a portable script-bearing artefact it "carries" authority and becomes a lifelong companion, almost like a fetish. ${ }^{26}$

All these locomobile artefacts can, as we already stated above, overcome barriers of space and multiply situations of reception and communication. They mediate between separate entities, linking and connecting people. And they possess a significant amount of agency, a distinct capacity to act and even to move. This is what distinguishes locomobile artefacts from locostatic ones, which tend to be media connecting to the past and to earlier texts. Inscriptions on tents, in contrast, offer an entrance to allegorical worlds of highly elaborated courtly love, suitable for the later stage of German courtly literature.

\section{Scholarly Contexts}

Gregorius's tablet has been a popular focus of studies in German scholarship. In fact, in contrast to other medieval literary traditions, medieval narrated inscriptions in general have received some attention from German scholars prior to Heidelberg University's CRC 933 on "Material Text Cultures”. Interestingly, the earliest stage of this research tradition was initiated also at Heidelberg University at the beginning of the twentieth century under the auspices of Friedrich Panzer, who became a professor of German Studies at the university in $1919 .{ }^{27}$ During the 1920 s and 1930 s he proposed a scholarly endeavour called Inschriftenkunde (Inscription Studies). His guides were the extensive collections of Latin and Greek inscription, the Corpus Inscriptionum Latinarum and Inscriptiones Graecae gathered by German scholars in the nineteenth century. Panzer desired a comparable collection from German-speaking areas and proposed to assemble one. This project, fuelled by the nationalistic atmosphere of early twentieth-century Europe, was meant to highlight a uniquely German medieval heritage in material and textual culture. This political and social environment helped to make Panzer's plan successful. In 1934 the German and Austrian Academies of Science indeed decided to fund the project to collect historical inscriptions from the Middle Ages until the end of the Thirty Years' War. This project exists to this day and continues to publish editions of Latin and German inscriptions.

26 For a more detailed discussion of the tablet with regard to its entanglement of things and persons see Ott 2015b.

27 For Panzer and his project of Inscription Studies see Ott 2014. 
Interestingly, Panzer had planned on collecting not only historic inscriptions but literary inscriptions as well. What may sound unusual at first actually corresponds to the nineteenth-century tradition of Germanistik, which aimed to cover the entirety of Germanic culture. In this context, historic and literary inscriptions go together very well. Panzer's wish, however, was not fulfilled; it was left to others to research and collect narrated inscriptions in medieval literature. The first to do so was Nikolaus Henkel who, in 1992, published a collection of narrated inscriptions, recording 70 instances (of which 26 had already been recorded by Panzer). ${ }^{28}$ Henkel is puzzled by the fact that there are quite a lot of narrated Middle High German inscriptions but few "real" German inscriptions during the early and High Middle Ages. Hence his collection serves primarily as a means of comparison between historical and literary inscriptions, but does not provide detailed analysis or the interpretation of the narrated inscriptions he has collected. In 2006, in contrast, Ulrich Ernst published a study on medieval text cultures. ${ }^{29}$ His interest lies in the field of Media Studies and he surveys a huge amount of mainly literary texts with regard to various forms of writing. Ernst's collection supplements that of Henkel and provides more information about the textual context and function of narrated inscriptions.

The CRC subproject C05 is working to continue the scholarship done by Panzer, Henkel and Ernst and to enlarge the hitherto existing collection by incorporating examples from less well known genres and texts, as well as by creating and using databases to efficiently search for relevant text passages. In these endeavours we have, for instance, examined particular genres and certain types of artefacts more closely. ${ }^{30}$ Nevertheless, while such collecting is important, contemporary scholars should aim to do something more with the information they gather. Using theoretical frameworks informed by Material Culture Studies, participants in the CRC subproject have studied narrated inscriptions in terms of mobility and space, the interfaces between script-bearing artefacts and their recipients, and the role of particular materials. ${ }^{31}$ The work we have done in developing some overall hypotheses about narrated inscriptions also intervenes in the still influential scholarly discussion around orality and literacy, as well as in considerations of the relationships between texts and images in the Middle Ages. ${ }^{32}$ Within the framework of these broader theoretical questions, we have analysed the significance of script-bearing artefacts in terms of their individual narrative contexts, on the one hand, and in terms of their broader cultural significance, on the other. We also abandon, of course, the nationalistic premises of the early twentieth century and expand our collection by including other languages and literatures. What once began as a project to identify the distinctly German is now a project that

28 See Henkel 1992.

29 See Ernst 2006.

30 See Lieb 2008; Ott/Pantanella 2014; See Lieb/Wagner 2017; Ott 2015a, 2015b.

31 See Lieb/Ott 2015, 2016; Ott 2017.

32 See Lieb 2015. 
seeks to understand German literature in a broader context and to identify relationships and connections using recent scholarship from diverse fields of research.

\section{Works Cited}

\section{Primary Sources}

Gottfried von Straßburg (2004), Tristan, ed. by Karl Marold, trans. by Peter Knecht, Berlin/New York. Hartmann von Aue (19856), Erec, first ed. by Albert Leitzmann (continued by Ludwig Wolff), latest ed. by Christoph Cormeau and Kurt Gärtner (Altdeutsche Textbibliothek 39), Tübingen. Hartmann von Aue (2004 ${ }^{15}$ ), Gregorius, ed. by Hermann Paul and Burghart Wachinger (Altdeutsche Textbibliothek 2), Tübingen.

Heinrich von Morungen, in: Des Minnesangs Frühling (1988 ${ }^{38}$ ), ed. by Hugo Moser and Helmut Tervooren, Stuttgart.

Hugo von Montfort (2005), Das poetische Werk. Texte, Melodien, Einführung, ed. by Wernfried Hofmeister, Berlin/New York.

Der Pfaffe Konrad (2007), Das Rolandslied, ed., trans. and annotated by Dieter Kartschoke, Stuttgart. Der Pfaffe Lambrecht (2007), Alexanderroman, ed., trans. and annotated by Elisabeth Lienert, Stuttgart.

Suchenwirt, Peter (1827), Di schoen Abentewr, in: Peter Suchenwirts Werke aus dem vierzehnten Jahrhunderte. Ein Beytrag zur Zeit- und Sittengeschichte, ed. by Alois Primisser, Wien.

Ulrich von Etzenbach (1888), Alexander, ed. by Wendelin Toischer (Bibliothek des litterarischen Vereins in Stuttgart 183), Tübingen.

Ulrich von Zatzikhoven (20132), Lanzelet, ed., trans. and annotated by Florian Kragl, Berlin/Boston. Wirnt von Grafenberg (2014²), Wigalois, ed. by J. M. N. Kapteyn, trans. and annotated by Sabine Seelbach and Ulrich Seelbach, Berlin/Boston.

Wolfram von Eschenbach (20032), Parzival, ed. by Karl Lachmann, trans. by Peter Knecht, Berlin/ Boston.

Wolfram von Eschenbach (2003), Titurel, ed. by Helmut Brackert and Stephan Fuchs-Jolie, Berlin/ New York.

Wolfram von Eschenbach (2004), Parzival. With Titurel and the Love-Lyrics, trans. by Cyril Edwards (Arthurian Studies), Cambridge.

\section{Secondary Sources}

Cohen, Jeffrey Jerome (2015), Stone. An Ecology of the Inhuman, Minneapolis/London.

Colliot, Regine (1973), “Les epitaphes arthuriennes”, in: Bibliographical Bulletin of the Arthurian Society 25, 155-175.

Ehlich, Konrad (1994), "Funktion und Struktur schriftlicher Kommunikation”, in: Hartmut Günther and Otto Ludwig (eds.), Schrift und Schriftlichkeit / Writing and its Use. Ein interdisziplinäres Handbuch internationaler Forschung / An Interdisciplinary Handbook of International Research (Handbuch zur Sprach- und Kommunikationswissenschaft 10,1), Berlin/New York, 18-41.

Ernst, Urlich (2006), Facetten mittelalterlicher Schriftkultur. Fiktion und Illustration. Wissen und Wahrnehmung (Beihefte zum Euphorion 51), Heidelberg. 
Henkel, Nikolaus (1992), "Die Stellung der Inschriften des deutschen Sprachraums in der Entwicklung volkssprachiger Schriftlichkeit”, in: Renate Neumüllers-Klauser (ed.), Vom Quellenwert der Inschriften (Vorträge und Berichte der Fachtagung Esslingen 1990), Heidelberg, 161-187.

Keith, Alison (ed.) (2011), Latin Elegy and Hellenistic Epigram. A Tale of Two Genres at Rome, Newcastle upon Tyne.

Klingner, Jacob (2013), "Zelte der Minne. Beobachtungen zu einem Handlungsort der mittelhochdeutschen Minnereden”, in: Gesine Mierke and Christoph Fasbender (eds.), Wissenspaläste. Räume des Wissens in der Vormoderne (Euros. Chemnitzer Arbeiten zur Literaturwissenschaft 2), Würzburg, 223-237.

Klingner, Jacob/Lieb, Ludger (eds.) (2013), Handbuch Minnereden, 2 vols., Berlin/Boston.

Lembke, Astrid (2017), “Die Toten im dritten Raum. Grabmäler als Orte der Begegnung zwischen Angehörigen verschiedener Religionen bei Wolfram von Eschenbach und Wirnt von Grafenberg", in: Seminar 53 (1), 21-42.

Lieb, Ludger (2008), “Minne schreiben. Schriftmetaphorik und Schriftpraxis in den 'Minnereden' des späten Mittelalters", in: Mireille Schnyder (ed.), Schrift und Liebe in der Kultur des Mittelalters (Trends in Medieval Philology 13), Berlin/New York, 191-220.

Lieb, Ludger (2015), "Spuren materialer Textkulturen. Neun Thesen zur höfischen Textualität im Spiegel textimmanenter Inschriften”, in: Beate Kellner, Ludger Lieb and Stephan Müller (eds.), Höfische Textualität. Festschrift für Peter Strohschneider, Heidelberg 2015, 1-20.

Lieb, Ludger/Ott, Michael R. (2015), "Schrift-Träger. Mobile Inschriften in der deutschsprachigen Literatur des Mittelalters", in: Annette Kehnel and Diamantis Panagiotopoulos (eds.), Schriftträger - Textträger. Zur materialen Präsenz des Geschriebenen in frühen Gesellschaften (Materiale Textkulturen 6), Berlin/München/Boston, 17-38.

Lieb, Ludger/Ott, Michael R. (2016), "Schnittstellen. Mensch-Artefakt-Interaktion in deutschsprachigen Texten des 13. Jahrhunderts", in: Friedrich-Emanuel Focken and Michael R. Ott (eds.), Metatexte. Erzählungen von schrifttragenden Artefakten in der alttestamentlichen und mittelalterlichen Literatur (Materiale Textkulturen 15), Berlin/Boston, 265-279.

Lieb, Ludger/Wagner, Ricarda (2017), "Dead Writing Matters? Materiality and Presence in Medieval German Narrations of Epitaphs", in: Irene Berti et al. (eds.), Writing Matters. Presenting and Perceiving Monumental Inscriptions in Antiquity and the Middle Ages (Materiale Textkulturen 14), Berlin/Boston, 15-26.

Maddox, Donald (2000), “'A tombeau ouvert'. Memory and Monuments in the Prose Lancelot”, in: Keith Busby and M. Catherine Jones (eds.), "Por le soie amisté". Essays in Honor of Norris J. Lacy, Amsterdam, 323-338.

Ott, Michael R./Pantanella, Flavia (2014), “Geschriebenes erzählen. Erzählte Inschriften in Minnereden aus narrativer, poetologischer und materialer Perspektive”, in: Iulia-Emilia Dorobanţu, Jacob Klingner and Ludger Lieb (eds.), Zwischen Anthropologie und Philologie. Beiträge zur Zukunft der Minneredenforschung, Heidelberg, 329-362.

Ott, Michael R. (2014), "Philologie der Worte und Sachen. Friedrich Panzers Inschriftenforschung als disziplinäre Herausforderung", in: Deutsche Vierteljahrsschrift für Literaturwissenschaft und Geistesgeschichte 88 (2), 234-255.

Ott, Michael R. (2015a), "Der Held, die Waffe, die Schrift. Aspekte einer Dreiecksbeziehung in deutschsprachigen Texten des 13. Jahrhunderts", in: helden. heroes. héros. E-Journal zu Kulturen des Heroischen 3 (2), 59-65.

Ott, Michael R. (2015b), “Die Tafel des Gregorius als schrifttragendes Artefakt”, in: Zeitschrift für Germanistik 25 (1), 253-267.

Ott, Michael R. (2017), “Erzählte Bauminschriften zwischen Antike und Früher Neuzeit”, in: Ludger Lieb, Stephan Müller and Doris Tophinke (eds.), Graffiti. Deutschsprachige Auf- und Inschriften in sprach- und literaturwissenschaftlicher Perspektive (Stimulus 24), Wien, 23-39. 
Petrucci, Armando (1998), Writing the Dead. Death and Writing Strategies in the Western Tradition, trans. by Michael Sullivan, Stanford.

Ramsby, Teresa R. (2007), Textual Permanence. Roman Elegists and the Epigraphic Tradition, London 2007.

Stock, Markus (2005), “Das Zelt als Zeichen und Handlungsraum in der hochhöfischen deutschen Epik. Mit einer Studie zu Isenharts Zelt in Wolframs Parzival”, in: Burkhard Hasebrink et al. (eds.), Innenräume in der Literatur des deutschen Mittelalters, Oxford, 67-86.

Wandhoff, Haiko (2003), Ekphrasis. Kunstbeschreibungen und virtuelle Räume in der Literatur des Mittelalters (Trends in Medieval Philology 3), Berlin.

Witthöft, Christiane (2013), “Finalität. Grabinschriften in der Untergangserzählung des Prosalancelot”, in: Udo Friedrich, Andreas Hammer and Christiane Witthöft (eds.), Anfang und Ende: Formen narrativer Zeitmodellierung in der Vormoderne (Literatur - Theorie - Geschichte 3), Berlin, 243-266.

Worstbrock, Franz Josef (1999), “Wiedererzählen und Übersetzen”, in: Walter Haug and Burghart Wachinger (eds.), Mittelalter und frühe Neuzeit. Übergänge, Umbrüche und Neuansätze (Fortuna vitrea 16), Tübingen, 128-142. 
